\title{
Phenotypic plasticity of eddoe and dasheen taro genotypes in response to saturated water and dryland cultivations
}

\author{
CARECA SEPDIHAN RAHMAT HIDAYATULLAH ${ }^{1}$, EDI SANTOSA $^{2, \bullet}$, DIDY SOPANDIE $^{2}$, \\ ARIEF HARTONO ${ }^{3}$ \\ ${ }^{1}$ Graduate School of Agronomy and Horticulture, Faculty of Agriculture, Institut Pertanian Bogor. Jl Meranti, Kampus IPB Darmaga, Bogor 16680, West \\ Java, Indonesia \\ ${ }^{2}$ Department of Agronomy and Horticulture, Faculty of Agriculture, Institut Pertanian Bogor. J1 Meranti, Kampus IPB Dramaga, Bogor 16680, West \\ Java, Indonesia. Tel.: +62-251-8629353, Fax.: +62-251-8629353, •email: edisang @gmail.com \\ ${ }^{3}$ Departement of Soil Science and Land Resources, Faculty of Agriculture, Institut Pertanian Bogor. J1 Meranti Kampus IPB Darmaga, Bogor 16680, \\ West Java, Indonesia
}

Manuscript received: 29 July 2020. Revision accepted: 10 September 2020.

\begin{abstract}
Hidayatullah CSR, Santosa E, Sopandie D, Hartono A. 2020. Phenotypic plasticity of eddoe and dasheen taro genotypes in response to saturated water and dryland cultivations. Biodiversitas 21:4550-4557. The phenotypic plasticity of dasheen and eddoe taro genotypes was evaluated based on growth and yield characters to select proper genotypes in response to climate change. The st udy was conducted at the Leuwikopo Experimental Farm, Bogor, Indonesia from May to October 2019. Dasheen (Talas Sutra and Talas Bentul) and eddoe genotypes (S28 and S19) were planted in saturated water cultivation (SWC) and dryland cultivation (DC). DC relied on rainwater, and SWC was manipulated dryland by flooding. SWC promoted vigorous growth and tuber weight, irrespective of genotypes. Increasing taro biomass production in SWC was supported by higher photosynthetic rate, leaf number, and size. Dasheen genotypes produced higher tuber weight than the eddoe in SWC, conversely, the eddoe tended to produced heavier tuber than the dasheen in DC; indicating phenotypic plasticity is strongly affected by soil moisture and genotype. The dasheen had more plastic growth and yield characters to soil moisture than the eddoe genotypes, with plasticity level, ranging from low to very high. Taro had high resiliency to multiple abiotic stresses, e.g. flood, and drought. Considering the marketable value of the yield, dasheen and eddoe genotypes are recommended in flooding and drought-prone areas, respectively.
\end{abstract}

Keywords: Climate change, Colocasia esculenta, drought, multiple abiotic stress, yield

\section{INTRODUCTION}

Phenotypic plasticity evaluation is an important aspect concerning changing climate that had broad implications to crop and animal production (Santosa et al. 2018a; 2019; Arnold et al. 2019; Bonamour et al. 2019). Many agronomists address climate change to particular crops to the presence of abiotic stress due to flooding (water excess) or drought (water deficit) (Striker 2012; Dulbari et al. 2017; Santosa et al. 2018b).

The effect of flooding and drought have been intensively studied on growth and production in many species (Santosa et al. 2004; Sugiyama and Santosa 2008; Sagala et al. 2011; Wairiu et al. 2012; Morales-Olmedo et al. 2015; Ganança et al. 2018). According to Sagala et al (2011) and Ganança et al (2018), response to the water excess and drought depends on crop variety. Hypoxia causes tuber rot in the Amorphophallus species (Sugiyama and Santosa 2008). In sweet potato, light flooding stimulates leaves growth and tuber weight (Hetharie et al. 2018). Wairiu et al (2012) noted drought reduces taro yield by up to $40 \%$. Nevertheless, there are a few reports that evaluate both abiotic stresses from a single perspective. In rice, drought and flood tolerance could be regulated by the coexist mechanism (Rubaiyath bin Rahman and Zhang 2016).
Taro (Colocasia esculenta L. Schott) is a member of Araceae which is widely cultivated in tropical and subtropical regions supported by diverse genotypes and agro-ecologies (Chaïr et al. 2016). In tropical countries like Indonesia, taro growing is important to secure household food and earn cash in local trading (Nurbaya and Estiasih, 2013). About 253 local varieties exist in Indonesia (BB BIOGEN 2020). Here, taro cultivation distributes in both wetland and dryland (Maretta et al. 2020). To help farmers to adapt changing climates, therefore, it is important to evaluate Indonesian taro genotypes under flooding and drought scenarios from a single perspective.

Based on the tuber shape, taro has two morphotypes namely eddoe (Colocasia esculenta var antiquorum) which produce many tubers, and dasheen (Colocasia esculenta var esculenta) which predominantly produce a single tuber (Ivancic and Lebot 2000; Chaïr et al. 2016). In Indonesia, dasheen type is more common (Nurbaya and Estiasih 2013), and eddoe type is a new introduction (Maretta et al. 2020). The present study aims to evaluate phenotypic plasticity of growth and production characters of eddoe and dasheen taro genotypes grown in saturated water and dryland cultivations to select proper genotype in response to climate change. 


\section{MATERIALS AND METHODS}

The study was conducted during the dry season at the Leuwikopo Experimental Station, Bogor Agricultural University (IPB), Bogor, Indonesia (-6.549398, 106.71615; $240 \mathrm{~m}$ above sea level) from May to October 2019. The soil type was Latosol. Mid-day temperature during research ranged from 21 to $38{ }^{\circ} \mathrm{C}$ (average $26.5^{\circ} \mathrm{C}$ ), relative air humidity ranged 61 to $88 \%$ (average $77.4 \%$ ), and monthly precipitation ranged 0.3 to $131.5 \mathrm{~mm}$ (average $21.5 \mathrm{~mm}$ ).

The study used a nested design with a cultivation system as the main factors: saturated water cultivation (SWC) and dryland cultivation (DC). The second factor as subplot was four taro genotypes, i.e., two dasheen (Talas Sutra and Talas Bentul) and two eddoe types (S28 and S19). SWC was manipulated by puddling dryland and flooding for three months before planting using irrigation water. DC received irrigation from rainwater. SWC and DC field is separated by $4 \mathrm{~m}$. Each treatment combination was repeated three times. Sutra and Bentul propagates were collected from farmers in Setuletik Village-Bogor, while S28 and S19 were obtained from the Agency for the Assessment and Application of Technology (BPPT), South Tangerang, Banten.

Before planting, SWC soil had $0.07 \%$ total N, 22.24 ppm available $\mathrm{P}, 0.40 \mathrm{cmol} \mathrm{kg}^{-1}$ exchangeable-K, $55.54 \mathrm{mg}$ $\mathrm{g}^{-1}$ total $\mathrm{P}$, and $29.33 \mathrm{mg} \mathrm{g}^{-1}$ total $\mathrm{K}$. The $\mathrm{SWC}$ soil had a $\mathrm{pH}\left(\mathrm{H}_{2} \mathrm{O}\right)$ 5.27. The dryland had total $\mathrm{N}$, available $\mathrm{P}$, exchangeable $\mathrm{K}$, total $\mathrm{P}$, and total $\mathrm{K}$ were $0.05 \%$, 24.61 ppm, $0.36 \mathrm{cmol} \mathrm{kg}^{-1}, 74.93 \mathrm{mg} \mathrm{g}^{-1}$, and $29.33 \mathrm{mg} \mathrm{g}^{-1}$, respectively. The DC had soil $\mathrm{pH}\left(\mathrm{H}_{2} \mathrm{O}\right) 4.81$.

Taro seedling was planted after maintaining for 28 days in nursery. A month before planting, raised planting bed at $50 \mathrm{~cm}$ in width and $25 \mathrm{~cm}$ height was prepared. The distance between beds was $50 \mathrm{~cm}$. One week before planting, lime $\left(\mathrm{CaCO}_{3}\right) 1$ ton $\mathrm{ha}^{-1}$ and cow manure 10 tons $\mathrm{ha}^{-1}$ were applied. At planting, all leaves were thinned out except an unopened leaf, and the seedlings were dipped in fungicide mancozeb $2 \%$; and insecticide carbofuran was applied at rate $2 \mathrm{~g}$ per plant. The bulb was planted at depth of $10-15 \mathrm{~cm}$, six seedlings in a planting bed. Plant spacing used $50 \mathrm{~cm}$ within a row and $100 \mathrm{~cm}$ between rows. Each genotype used two beds.

SWC plot received water $20-30 \mathrm{~L} \mathrm{~m}^{-2}$ daily, and the water level was maintained $10-12 \mathrm{~cm}$ below the bed surface by installing an outlet. Weed control was conducted manually. NPK fertilizers used urea $(46 \% \mathrm{~N}) 100 \mathrm{~kg} \mathrm{ha}^{-1}$, SP-36 (36\% $\left.\mathrm{P}_{2} \mathrm{O}_{5}\right) 150 \mathrm{~kg} \mathrm{ha}^{-1}$, and $\mathrm{KCl}\left(60 \% \mathrm{~K}_{2} \mathrm{O}\right) 100 \mathrm{~kg}$ ha $^{-1}$ was applied at 8 weeks after planting (WAP) according to farmers' practices.

Observations were conducted 6-20 WAP with an interval of 2 weeks. Plant height was measured from the ground to the tip of the petiole. The number of leaves was calculated from the fully open leaves, and the number of suckers was calculated from those produced leaves. Stem diameter was observed at the ground surface. The total leaf area was observed by using the gravimetric method (Irwan and Wicaksono 2017). Harvesting was carried out at 20 WAP. Fresh weight of shoot, tuber, and roots was observed at harvest. Dry mass was evaluated after oven drying at $80^{\circ} \mathrm{C}$ until constant weight.

Plasticity $(\mathrm{P})$ of growth and production characters of particular genotype was evaluated based on the differences in performance in different cultivation systems. The approach using population characters (Arnold et al. 2019). Here, we used plasticity scored into low, medium, high, and very high corresponding to values: $0-25 \%, 26-50 \%$, $51-75 \%$, and $>75 \%$, respectively. The formula was: $P=\frac{\text { VSWC-VDC) } 10096}{V D C}$ VDC: value in dryland cultivation, VSWC: value in saturated water cultivation.

Soil redox potential was observed at 18 WAP followed Fiedler et al (2007). The redox was measured in six points in each planting bed using an Eh meter expressed in millivolts $(\mathrm{mV})$. The rate of photosynthesis, transpiration, and stomatal conductance was measured on the $3^{\text {rd }}$ leaf from the top using LI-COR 6400XT (LI-COR Inc., USA) at 16 WAP. Chlorophyll content was evaluated using spectrophotometry (Sims and Gamon 2002).

The data were tested for the variance. For any significant differences due to treatment, the data were further tested using Least Significant Different (LSD) $\alpha=$ $5 \%$.

\section{RESULTS AND DISCUSSION}

\section{Soil redox potential}

Saturated water soil had a $60.4 \%$ lower redox value than dryland (Table 1). The high difference in soil redox potential among SWC and DC was due to differences in soil moisture content. In the study site, the groundwater level was about $3 \mathrm{~m}$ below the soil surface. This situation led to distinct soil redox potential among cultivation systems. According to Virtanen et al (2017), soil redox potential $>350 \mathrm{mV}$ is classified as oxidative soils with high oxygen content, while $<350 \mathrm{mV}$ is classified as reductive conditions with low oxygen content. On the other hand, there was no significant difference in soil redox potential among genotypic plots.

Table 1. Soil redox potential of saturated water and dryland plots, and taro genotypes plots at $18 \mathrm{WAP}$

\begin{tabular}{ll}
\hline \multicolumn{1}{c}{ Treatment } & \multicolumn{1}{c}{ Redox potential $(\mathbf{m V})$} \\
\hline Cultivation system (L) & $176.3 \pm 73.9 \mathrm{~b}$ \\
Saturated water (SWC) & $393.1 \pm 26.6 \mathrm{a}$ \\
Dryland (DC) & \\
Genotypes (V) & $274.8 \pm 505.0$ \\
Sutra & $268.5 \pm 516.0$ \\
Bentul & $287.5 \pm 380.4$ \\
S28 & $308.1 \pm 437.8$ \\
S19 & $*$ \\
L factor & $\mathrm{ns}$ \\
V factor & $\mathrm{ns}$ \\
interaction L*V & \\
\hline
\end{tabular}

Note: Values on the same column followed by similar alphabet do

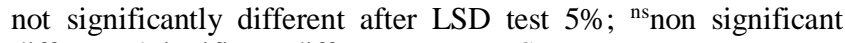
different, *significant different; Mean \pm SD 


\section{Plant growth}

The cultivation system and genotypes determined taro height (Figure 1). At harvest irrespective of cultivation system, Sutra, Bentul, S28, and S19 genotypes had a height of $101.3 \mathrm{~cm}, 110.6 \mathrm{~cm}, 82.03 \mathrm{~cm}$, and $27.11 \mathrm{~cm}$, respectively; indicating height variation among genotypes. IPGRI (1991) classifies taro height into a dwarf $(<50 \mathrm{~cm})$, medium $(50-100 \mathrm{~cm})$, and tall $(>100 \mathrm{~cm})$; based on the classification Sutra and Bentul are tall taro, S28 is medium and S19 is dwarf one.

In general, the taro height increased in SWC than in DC treatment (Figure 1). SWC stimulated the height of Sutra, Bentul, S28, and S19 by 104.2\%, 173.8\%, 269.4\%, and $176.5 \%$ compared to DC at 20 WAP. According to Mabhaudhi et al (2013), taro height increases $15 \%$ in $100 \%$ water availability than the plant receives only $30 \%$ water availability. Likely, the height of the dasheen type increased steadily every week until harvest in SWC, while the response of eddoe type depended on variety (Figure 1). S19 genotype reached the maximum height at 14 WAP, while S28 at 20 WAP (Figure 1C-D). In DC, maximum height was attained at about 10 WAP in all genotypes. The height of Sutra increased by $52.3 \%$ and S19 by $15.4 \%$ under SWC relative to DC during the growing period 12-20 WAP. Height of S19 was stable around $20-30 \mathrm{~cm}$ at $10-20$ WAP under SWC and the crop had a shorter size on DC. In sunflowers, drought inhibits cell division and development causes stunting (Hussain et al., 2008). Judgment from marked height fluctuation in eddoe type among cultivation system indicating its sensitivity to water fluctuation; S28 genotype had more sensitivity than S19 genotype.

There was an interaction between the cultivation system and genotypes on the leaf number at 6, 12, 14, and 18 WAP. Leaf number increased from planting to 10-12 WAP (Figure 2). Sutra, Bentul, S28, and S19 genotypes under SWC had a higher number of leaf $77.5 \%, 48.9 \%, 180.8 \%$, and $100 \%$ than those in DC at 18 MST, respectively. Low leaf number of taro under dry condition is common as a phenotypic adaptation mechanism to reduce excess transpiration (Ganança et al. 2018) and due to premature leaf aging (Sahoo et al. 2008; Mabhaudhi et al. 2013). Genetically, it seems that the dasheen type had a larger leaf number than eddoe type, irrespective of the cultivation system. Dasheen had maximum leaf number 8-9 and eddoe had 5-8 in SWC, while 5-6 of dasheen and 3-4 of eddoe type in DC. Here, S28 and S19 did not show premature leaf aging in DC treatment, which means that genotype might determine leaf production.

The cultivation system and genotype had an interaction on the number of sucker and stem diameter, but no interaction was present for the leaf area character (Table 2). The number of suckers, stem diameter, and leaf area was sensitive to soil moisture and genotype. SWC stimulated sucker production in all genotypes; for example, Sutra produced an additional 4.5 suckers and S28 produced an additional 2.6 suckers relative to DC. Sucker is a daughter bulb of eddoe or stolon of dasheen types that produce leaf. The farmer usually removed sucker of dasheen type to maximize the production, but the sucker of eddoe is unlikely. Sucker has no marketable value in eddoe yield. It is prospective to increase the marketable number of eddoe bulbs through controlling soil moisture.

Within a cultivation system, each dasheen and eddoe group had a similar total leaf area (Table 2). Irrespective of genotype, the leaf area in DC was $63.01 \%$ than that in SWC. Among genotypes, only Bentul that expressed a marked reduction in DC, decreased $48.24 \%$ from SWC. Here, the only leaf derived from the main bulb was considered. Indeed, the dasheen genotype consistently had a larger leaf area than those of eddoe genotype in both SWC and DC. The Bentul leaves probably are the most plastic to soil moisture than the other genotypes. However, it is still unclear why the Bentul leaf area exhibited high plasticity to soil moisture than the other genotypes.

Table 2. Number of suckers, leaf area, and stem diameter of taro genotype growing in saturated water and dryland cultivations at harvest (20 WAP)

\begin{tabular}{lllll}
\hline Cultivation system $(\mathbf{L})$ & Genotypes $(\mathbf{V})$ & Sucker number & Total leaf area $\left(\mathbf{c m}^{2}\right)$ & Pseudostem diameter $(\mathbf{c m})$ \\
\hline \multirow{2}{*}{ Water saturated (SWC) } & Sutra & $6.3 \pm 1.0 \mathrm{a}$ & $387.9 \pm 87.1 \mathrm{ab}$ & $9.5 \pm 0.4 \mathrm{a}$ \\
& Bentul & $4.5 \pm 0.3 \mathrm{ab}$ & $474.7 \pm 136.0 \mathrm{a}$ & $10.1 \pm 0.2 \mathrm{a}$ \\
& S28 & $3.5 \pm 0.3 \mathrm{bc}$ & $174.0 \pm 45.1 \mathrm{c}$ & $6.1 \pm 0.8 \mathrm{~b}$ \\
Dryland (DC) & S19 & $2.9 \pm 1.9 \mathrm{bcd}$ & $159.1 \pm 62.9 \mathrm{c}$ & $2.4 \pm 0.8 \mathrm{~cd}$ \\
& Sutra & $1.8 \pm 0.7 \mathrm{~cd}$ & $289.3 \pm 77.2 \mathrm{abc}$ & $3.6 \pm 0.3 \mathrm{c}$ \\
& Bentul & $1.6 \pm 0.5 \mathrm{~cd}$ & $245.7 \pm 31.3 \mathrm{bc}$ & $2.8 \pm 0.7 \mathrm{c}$ \\
& S28 & $0.9 \pm 0.6 \mathrm{~d}$ & $98.2 \pm 40.7 \mathrm{c}$ & $2.1 \pm 0.8 \mathrm{~cd}$ \\
L factor & S19 & $1.0 \pm 0.0 \mathrm{~d}$ & $120.2 \pm 37.8 \mathrm{c}$ & $0.9 \pm 0.3 \mathrm{~d}$ \\
V factor & & $*$ & $*$ & $*$ \\
L*V & & $*$ & ns & $*$ \\
\end{tabular}

Note: Value on the same column followed by similar alphabet do not significantly different after LSD test 5\%; ${ }^{\text {ns }}$ non significant different, *significant different; Mean \pm SD 

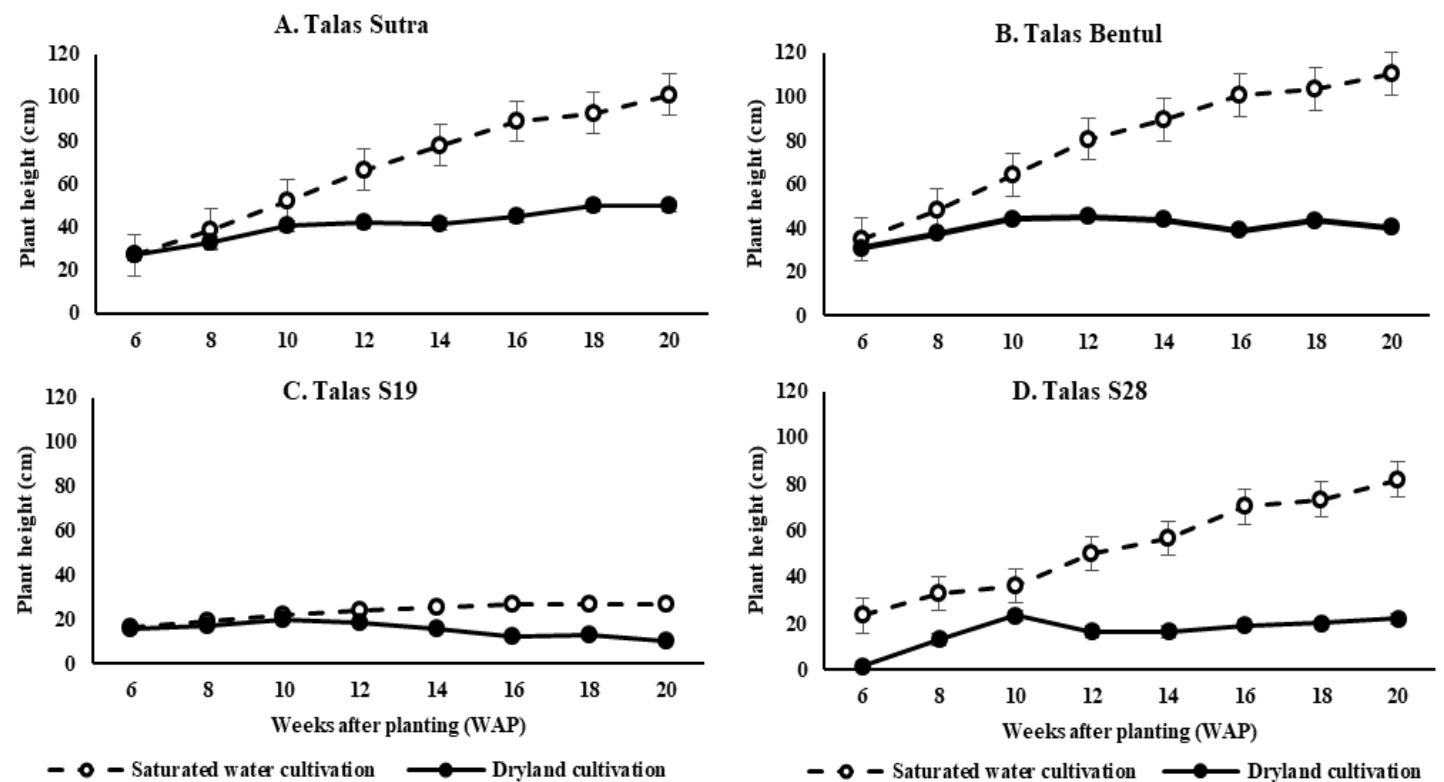

Figure 1. Plant height of taro genotypes on different cultivation systems at 6-20 WAP

A. Talas Sutra
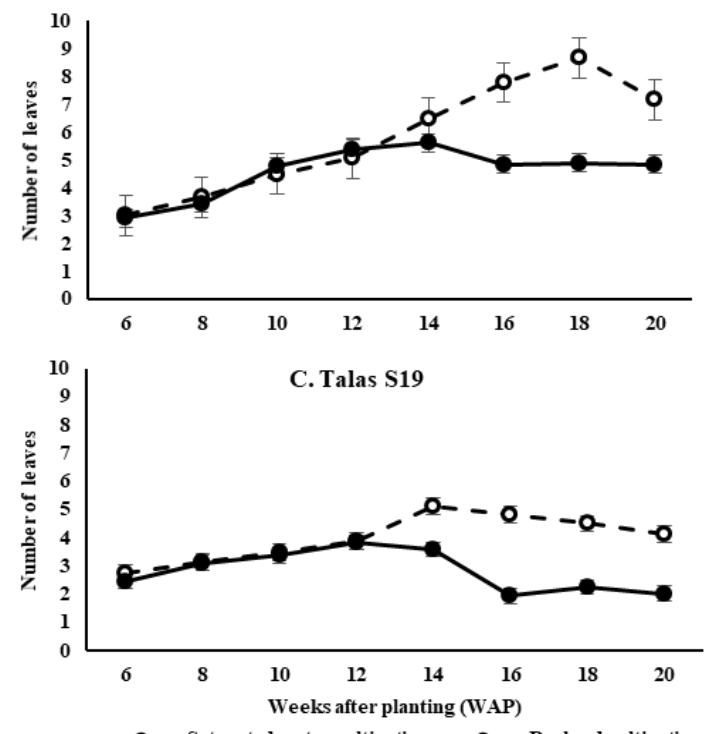

B. Talas Bentul
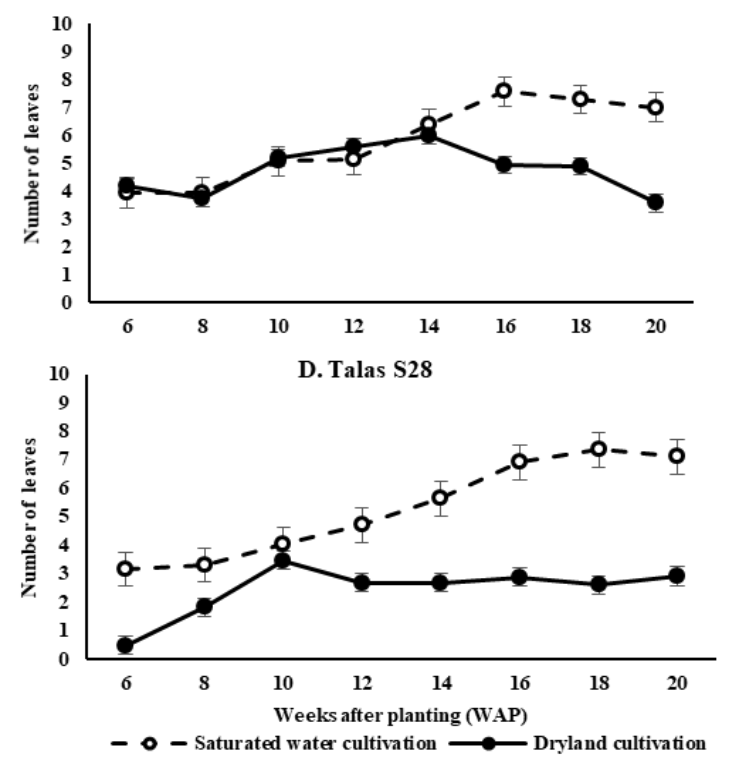

Figure 2. Leaf number of taro genotypes on different cultivation systems at 6-20 WAP

Regardless of the genotype, the pseudostem diameter of taro decreased by $66.45 \%$ in DC relative to SWC (Table 2), which indicated the sensitivity of pseudostem diameter to soil moisture. On average, pseudostem diameter was 7.0 $\mathrm{cm}$ in SWC while $2.4 \mathrm{~cm}$ in DC. Among taro groups, reduction value was nearly similar, i.e., $67.35 \%$ and $64.71 \%$ for dasheen and eddoe types, respectively. Within eddoe taro type, DC reduced pseudostem diameter by $65.57 \%$ in $\mathrm{S} 28$ and $62.50 \%$ in $\mathrm{S} 19$. High reduction in diameter could be due to morphologically pseudostem composes of the spongy vessel that its expansion is determined by water availability. In Amorphophallus muelleri, petiole diameter has a high correlation with tuber diameter (Santosa et al. 2003). It needs further study by using different levels of soil water level to evaluate the usefulness of pseudostem diameter as morphometric to estimate taro size in different cultivation systems.

\section{Chlorophyll content}

Level of chlorophyll-a, -b, and total $a+b$ were determined by cultivation system and genotypes (Table 3 ). The ratio of chlorophyll $\mathrm{a} / \mathrm{b}$ was affected by interactions between the cultivation system and genotypes. Eddoe taro tended to have lower chlorophyll-a, $-\mathrm{b}$, and total $\mathrm{a}+\mathrm{b}$ as compared to dasheen genotypes. 
Taro grown in DC had higher chlorophyll content but lower in the ratio of chlorophyll $a / b$ than in SWC, irrespective genotypes (Table 3). For example, Sutra in DC had chlorophyll-a, -b, and total a+b of $100 \%, 66.7 \%$, and $91.0 \%$ higher than in SWC, respectively. This finding in line with studies in many plants where waterlogging decreases chlorophyll content (Ren et al. 2016; Tian et al. 2019). Ren et al (2016) stated that corn under waterlogging has lower chlorophyll content leading to have a lower yield. According to Gosavi et al (2014), reduction in the level of chlorophyll-b during stress is influenced by the accumulation of proline, antioxidant content, and genotype.

Irrespective genotypes, taro had a higher ratio of chlorophyll $\mathrm{a} / \mathrm{b}$ in SWC than that in DC, i.e., 2.8-2.9 and 2.5-2.7, respectively (Table 3). Teiz and Zeiger (2002) stated that chlorophyll-b is a light-harvesting pigment and transmits the electrons to chlorophyll-a for the photosynthetic process. Here, the chlorophyll-a level increased by $27.20 \%$ while chlorophyll-b increased by $39.79 \%$ in DC relative to SWC. Thus, taro in DC had a wider light-harvesting antenna than those in SWC.

\section{Photosynthetic and transpiration rates, and stomatal conductance}

Taro genotypes did not show any significant difference in rates of photosynthetic and transpiration, and stomatal conductance, unlike the cultivation system that significantly affected the rate of photosynthetic and transpiration (Table 4). The photosynthetic rate in SWC was $60.4 \%$ higher than that in DC, conversely, the transpiration rate in SWC was $23.8 \%$ lower than that in DC. According to Anjum et al (2011), leaf photosynthetic is lower in drought.

We expected the photosynthetic rate of taro in DC higher than SWC judged from the higher chlorophyll content in DC (Table 3), however, it was unlikely (Table 4). The low photosynthetic rate in DC was probably due to a lack of water. In the field, we notified that leaves of all genotype slightly withered during the daytime. According to Mabhaudhi and Modi (2015), the decreasing photosynthetic rate is a physiological response adapting to drought by closing the stomata. However, in this research, there was no difference in stomatal conductance among genotypes and cultivation systems (Table 4).

The transpiration rate was similar among genotypes, but taro from dryland cultivation had a higher transpiration rate (Table 4). Transpiration rate was markedly high in DC, i.e. $6.3 \mathrm{mmol} \mathrm{H}_{2} \mathrm{O} \mathrm{m}^{-2} \mathrm{~s}^{-1}$ compared to SWC $4.8 \mathrm{mmol} \mathrm{H}_{2} \mathrm{O} \mathrm{m}^{-}$ ${ }^{2} \mathrm{~s}^{-1}$. Table 2 shows that taro growing in DC had a narrower leaf area than in SWC. It seems that the reduction of leaf number and leaf area especially Bentul is a mechanism to reduce the transpiration rate that commonly high in DC. Gouveia et al (2019) noted the reduction in leaf area is a morphological strategy to reduce over-transpiration. Therefore, Bentul could be a good model of taro in the adaptation mechanism to soil water fluctuation.

Table 3. Chlorophyll content of taro genotypes growing in saturated water and dryland cultivations at 16 WAP

\begin{tabular}{llllll}
\hline Cultivation system $(\mathbf{L})$ & Genotypes $(\mathbf{V})$ & Chl-a $\left(\mathbf{m g ~ g}^{-\mathbf{1}}\right)$ & Chl-b $\left(\mathbf{m g ~ g}^{-\mathbf{1}}\right)$ & \multicolumn{1}{c}{ Chl a+b $\left(\mathbf{m g ~ g}^{-\mathbf{1}}\right)$} & Ratio a/b \\
\hline Water saturated (SWC) & Sutra & $1.6 \pm 0.1 \mathrm{ab}$ & $0.5 \pm 0.0 \mathrm{~b}$ & $2.1 \pm 0.1 \mathrm{ab}$ & $2.90 \pm 0.03 \mathrm{a}$ \\
& Bentul & $1.5 \pm 0.1 \mathrm{ab}$ & $0.5 \pm 0.1 \mathrm{~b}$ & $2.0 \pm 0.2 \mathrm{ab}$ & $2.85 \pm 0.06 \mathrm{ab}$ \\
& S28 & $1.2 \pm 0.0 \mathrm{bc}$ & $0.4 \pm 0.0 \mathrm{bc}$ & $1.7 \pm 0.0 \mathrm{bc}$ & $2.78 \pm 0.09 \mathrm{abc}$ \\
& S19 & $0.8 \pm 0.4 \mathrm{c}$ & $0.3 \pm 0.1 \mathrm{c}$ & $1.1 \pm 0.5 \mathrm{c}$ & $2.76 \pm 0.03 \mathrm{abc}$ \\
Dryland (DC) & Sutra & $1.7 \pm 0.2 \mathrm{ab}$ & $0.6 \pm 0.1 \mathrm{ab}$ & $2.3 \pm 0.2 \mathrm{ab}$ & $2.61 \pm 0.02 \mathrm{~cd}$ \\
& Bentul & $2.0 \pm 0.4 \mathrm{a}$ & $0.8 \pm 0.2 \mathrm{a}$ & $2.7 \pm 0.5 \mathrm{a}$ & $2.53 \pm 0.10 \mathrm{~d}$ \\
& S28 & $1.5 \pm 0.2 \mathrm{ab}$ & $0.6 \pm 0.1 \mathrm{~b}$ & $2.0 \pm 0.3 \mathrm{ab}$ & $2.68 \pm 0.17 \mathrm{bcd}$ \\
L factor & S19 & $1.4 \pm 0.1 \mathrm{bc}$ & $0.5 \pm 0.0 \mathrm{~b}$ & $1.9 \pm 0.1 \mathrm{~b}$ & $2.52 \pm 0.06 \mathrm{~d}$ \\
V factor & & $*$ & $*$ & $*$ & $*$ \\
L*V & $*$ & $*$ & $\mathrm{~ns}$ & $*$ \\
\hline
\end{tabular}

Note: Values on the same column followed by similar alphabet do not significantly different after LSD test 5\%; ${ }^{\text {ns }}$ non significant different, *significant different; Mean \pm SD

Table 4. Photosynthetic and transpiration rates, and stomatal conductance of taro genotypes growing in different cultivation system at 16 WAP

\begin{tabular}{|c|c|c|c|}
\hline Treatment & $\mathrm{A}\left(\mu \mathrm{mol} \mathrm{CO} \mathrm{CO}^{-2} \mathbf{s}^{-1}\right)$ & $\operatorname{Tr}\left(\mu \mathrm{mol} \mathrm{H} \mathbf{H}_{2} \mathrm{O} \mathrm{m}^{-2} \mathrm{~s}^{-1}\right)$ & $\operatorname{gs}\left(\mu \mathrm{mol} \mathrm{H}_{2} \mathrm{O} \mathrm{m}^{-2} \mathrm{~s}^{-1}\right)$ \\
\hline \multicolumn{4}{|l|}{ Cultivation system (L) } \\
\hline Water saturated (SWC) & $17.0 \pm 5.4 \mathrm{a}$ & $4.8 \pm 2.6 \mathrm{~b}$ & $155.8 \pm 90.4$ \\
\hline Dryland (DC) & $10.6 \pm 3.3 \mathrm{~b}$ & $6.3 \pm 2.0 \mathrm{a}$ & $191.7 \pm 61.6$ \\
\hline \multicolumn{4}{|l|}{ Genotypes (V) } \\
\hline Sutra & $15.1 \pm 15.2$ & $4.9 \pm 2.9$ & $156.7 \pm 80.6$ \\
\hline Bentul & $14.3 \pm 11.7$ & $6.3 \pm 1.5$ & $186.7 \pm 41.3$ \\
\hline S28 & $13.7 \pm 17.3$ & $5.6 \pm 6.6$ & $173.3 \pm 191.7$ \\
\hline S19 & $12.1 \pm 10.4$ & $5.5 \pm 2.2$ & $178.3 \pm 91.1$ \\
\hline $\mathrm{L}$ factor & $*$ & $*$ & $\mathrm{~ns}$ \\
\hline $\mathrm{V}$ factor & ns & ns & $\mathrm{ns}$ \\
\hline $\mathrm{L}^{*} \mathrm{~V}$ & ns & ns & ns \\
\hline
\end{tabular}




\section{Biomass and tuber production}

Cultivation systems, genotypes, and their interaction significantly affected biomass production (Table 5). Taro from SWC had higher plant biomass than those from DC treatment, except the S19 genotype. Taro grown in DC attained the fresh weight of shoot, tuber, and root $7.65 \%$, $7.60 \%$, and $28.63 \%$ of those in SWC, indicating marked reduction in biomass production. The great reduction in biomass in DC was also found in dry weight of shoot, tuber, and root that reached only $8.62 \%, 4.76 \%$, and $18.15 \%$ than to those grown in SWC, respectively. The low taro production in dryland had been reported by Ganança et al (2018).

Table 5 shows the $\mathrm{S} 19$ genotype had the lowest biomass in SWC treatment. As compared to S28 as a similar member of the eddoe group, the S19 genotype produced $5.57 \%, 25.61 \%$, and $23.61 \%$ fresh weight of shoot, tuber, and root of the S28, respectively. Interestingly in SWC treatment, S28 genotypes and had similar fresh tuber weight 607.5-671.0 $\mathrm{g}$ and dry weight $115.7-173.5 \mathrm{~g}$ to all dasheen members. Conversely in DC treatment, there was no statistically different among dasheen and eddoe genotypes in both the fresh and dry weight of tuber (Table 5). Although eddoe taro in DC treatment produced similar fresh tuber weight to dasheen genotypes, the eddoe genotypes expressed higher variation in weight as shown by the larger standard deviation (SD). According to farmers in Bogor, the marketable size of dasheen taro is >300 g, meaning that under DC the dasheen is less than profitable. On the other hand, eddoe taro S28 and S19 abled to produce marketable yield under DC. Thus, in the droughtprone field, it is recommended to plant the eddoe rather than the dasheen genotypes.

\section{Plasticity characters and its usefulness in the cultivation system}

Phenotypic plasticity was apparent in taro on the characters of plant height, leaf number, sucker number, leaf area, pseudostem diameter, photosynthetic rate, and biomass production of both fresh and dry mass (Table 6). Santosa et al $(2018 \mathrm{a} ; 2019)$ have pointed out presence phenotypic plasticity in Amorphophallus muelleri, an Araceae member. Phenotypic plasticity probably becomes a common attribute in Araceae members. Sagala et al (2011) revealed that soybeans produced 7.0-8.5 times higher pod number under saturated cultivation than those in non-saturated cultivation.

Table 5. Fresh and dry weight of taro genotypes grown in saturated water and dryland cultivations at 20 WAP

\begin{tabular}{|c|c|c|c|c|c|c|}
\hline \multirow{2}{*}{$\begin{array}{c}\text { Genotypes } \\
\text { (V) }\end{array}$} & \multicolumn{3}{|c|}{ Fresh weight (g per plant) } & \multicolumn{3}{|c|}{ Dry weight (g per plant) } \\
\hline & Shoot & Tuber & Root & Shoot & Tuber & Root \\
\hline \multicolumn{7}{|c|}{ Water saturated (SWC) (L) } \\
\hline Sutra & $1892.6 \pm 346.8 \mathrm{a}$ & $607.5 \pm 136.1 \mathrm{a}$ & $38.7 \pm 10.6 b$ & $113.5 \pm 33.2 \mathrm{a}$ & $115.7 \pm 42.4 \mathrm{a}$ & $7.6 \pm 0.8 \mathrm{ab}$ \\
\hline Bentul & $1868.3 \pm 537.6 \mathrm{a}$ & $671.0 \pm 108.7 \mathrm{a}$ & $71.7 \pm 17.6 \mathrm{a}$ & $129.1 \pm 13.1 \mathrm{a}$ & $173.5 \pm 51.1 \mathrm{a}$ & $11.9 \pm 4.0 \mathrm{a}$ \\
\hline S28 & $520.8 \pm 172.8 b$ & $621.6 \pm 336.5 \mathrm{a}$ & $30.5 \pm 13.4 b$ & $25.1 \pm 4.7 b$ & $129.8 \pm 83.9 a$ & $6.3 \pm 1.7 \mathrm{bc}$ \\
\hline S19 & $29.0 \pm 7.5 \mathrm{c}$ & $159.2 \pm 37.8 b$ & $7.2 \pm 1.1 \mathrm{c}$ & $2.5 \pm 1.4 \mathrm{c}$ & $34.8 \pm 11.2 b$ & $1.2 \pm 0.7 \mathrm{~d}$ \\
\hline \multicolumn{7}{|c|}{ Dryland (DC) (L) } \\
\hline Sutra & $199.0 \pm 120.5 b c$ & $51.1 \pm 7.9 \mathrm{bc}$ & $13.0 \pm 3.0 \mathrm{c}$ & $13.2 \pm 8.8 \mathrm{bc}$ & $3.9 \pm 1.4 \mathrm{c}$ & $2.4 \pm 0.7 \mathrm{~cd}$ \\
\hline Bentul & $58.5 \pm 45.2 \mathrm{c}$ & $31.2 \pm 14.6 \mathrm{c}$ & $13.5 \pm 13.0 \mathrm{c}$ & $5.1 \pm 3.9 \mathrm{c}$ & $5.6 \pm 4.4 \mathrm{bc}$ & $1.2 \pm 0.8 \mathrm{~d}$ \\
\hline $\mathrm{S} 28$ & $47.2 \pm 29.7 \mathrm{c}$ & $33.0 \pm 22.3 \mathrm{c}$ & $10.1 \pm 7.0 \mathrm{c}$ & $3.4 \pm 2.0 \mathrm{c}$ & $6.1 \pm 6.1 b c$ & $0.9 \pm 0.7 \mathrm{~d}$ \\
\hline S19 & $25.0 \pm 9.1 \mathrm{c}$ & $41.2 \pm 16.3 \mathrm{c}$ & $5.8 \pm 0.5 \mathrm{c}$ & $1.6 \pm 0.1 \mathrm{c}$ & $6.0 \pm 2.9 \mathrm{bc}$ & $0.4 \pm 0.1 \mathrm{~d}$ \\
\hline $\mathrm{L}$ factor & $*$ & $*$ & $*$ & $*$ & $*$ & $*$ \\
\hline $\mathrm{V}$ factor & $*$ & $*$ & $*$ & $*$ & $*$ & $*$ \\
\hline $\mathrm{L}^{*} \mathrm{~V}$ & $*$ & $*$ & $*$ & $*$ & $*$ & $*$ \\
\hline
\end{tabular}

Note: Value on the same column followed by similar alphabet do not significantly different after LSD test 5\%; *significant different after transformation $\sqrt{\mathrm{x}}+0.5 ;$ Mean $\pm \mathrm{SD}$

Table 6. Plasticity score of growth and production characters of taro genotypes grown in saturated water and dryland cultivations

\begin{tabular}{llllllllll}
\hline Genotype & $\begin{array}{c}\text { Plant } \\
\text { height }\end{array}$ & $\begin{array}{c}\text { Leaf } \\
\text { number }\end{array}$ & $\begin{array}{c}\text { Sucker } \\
\text { number }\end{array}$ & Leaf area & $\begin{array}{c}\text { Pseudo } \\
\text { diameter }\end{array}$ & Chl-a & Chl-b & Chl a+b & Chl a/b \\
\hline Sutra & VH & M & VH & M & VH & L & L & L & L \\
Bentul & VH & H & VH & VH & VH & L & M & M & L \\
S28 & VH & VH & VH & VH & VH & L & M & L & L \\
S19 & VH & M & VH & M & VH & M & M & M & L \\
& A & Tr & gs & F-shoot & F-tuber & F-root & D-shoot & D-tuber & D-root \\
Sutra & H & L & L & VH & VH & VH & VH & VH & VH \\
Bentul & M & L & L & VH & VH & VH & VH & VH & VH \\
S28 & VH & M & M & VH & VH & VH & VH & VH & VH \\
S19 & H & L & L & L & VH & L & M & VH & VH \\
\hline
\end{tabular}

Note: A: photosynthetic rate; Tr: transpiration rate; gs: stomatal conductance; F: shoot: the fresh weight of shoot; F: tuber: the fresh weight of tuber, F: root: the fresh weight of root; D: shoot: dry weight of shoot, D: tuber: dry weight of tuber, D: root: dry weight of root; L: low, M: medium, H: high, VH: very high 
Phenotypic plasticity in taro is highly related to soil moisture. In both dasheen and eddoe types, all growth variables exhibited a reduction in DC except for chlorophyll contents, transpiration rate, and stomatal conductance (Tables 3 and 4). The finding is in line with the results in other Araceae Amorphophallus paeoniifolius by Santosa et al (2004) where short-term soil drying reduces the size and number of cormels and root dry weight. Long term drying, like in DC treatment in the present experiment decreased tuber yield as reported as well by Ravi et al (2015) and Ganança et al (2018). According to Mabhaudi et al (2013) reduction of taro biomass in drought is due to a reduction in leaf size, and photosynthetic and transpiration rates.

The plasticity rate seemed to depend on genotype (Table 6). In dasheen taro, water excess as represented by SWC treatment advantaged growth and production, as indicated by vigorous plants resulting in higher tuber production (Table 5). Unlike in dasheen that almost had a consistent response, the responses of eddoe taro member S28 and S19 was slightly different. It is evident that water excess had a positive impact on both eddoe genotypes, but S28 had more responsive to saturated soil water than the S19 genotype. Maretta et al (2020) grouped eddoe taro into two distinct clades representing the different times of the introduction in Indonesia. Different genetic background of S19 and S28 probably contributes to different plasticity in the present experiment. Other possibilities, both genotypes are the results of long term selection in different agroecologies (Chaïr et al. 2016). According to Nurilmala et al (2017), Colocasia esculenta had high somaclonal variation up to $51 \%$ after gamma irradiation using 5-15 Gy.

The ability of taro to adapt to saturated water and dryland cultivations is interesting, especially in saturated water that had low soil redox potential (Table 1). According to Marschner (2012) soil with redox potential $<300 \mathrm{mV}$ has no free $\mathrm{O}_{2}$ and in $<250 \mathrm{mV}$ has no $\mathrm{NO}_{3}$ available. In saturated water, Singh and Setter (2017) noted the increase in the availability of toxic elements such as Fe, Mn, and Al. Although Sagala et al (2011) noted that continuous flooding inactive Fe toxicity. Probably, the ability of taro genotype growing in soil with saturated water relates to the ability of plants to minimize the effect of the toxicity elements and to coop with low oxygen availability; as part of amphibian characters. However, it needs further clarification.

Finally, under uncertainty climate resulting in flooding and drought incidents as the negative impact of climate change, planting amphibian taro is an advantage. Indeed in the agronomic perspective, stable crop production is important. In this case, a low phenotypic plasticity score indicates high stability of growth and production characters across the impact of climate change. In rice, Rubaiyath Bin Rahman and Zhang (2016) speculated the coexisting and cross-talking pathways on molecular mechanisms that control flooding and drought tolerance in a single genotype. Setyowati and Minantyorini (2016) pointed out that taro genotypes determine their suitability to a particular environment, such as Ketan and Kimpul are only suitable for unfertile soils while Karangasem and Sutra are suitable for fertile soils. In the future, it is interesting to study the physiological and genetic mechanism in taro that controls responses to diverse agro-ecologies to develop an effective breeding strategy with more resilient agronomic characters to multiple abiotic stress such as flooding and drought in a single perspective.

In conclusion, taro exhibited phenotypic plasticity on characters of growth and yield in response to saturated water and dryland cultivations. The plasticity level was also affected by genotype. Saturated water cultivation (SWC) benefit taro vigor of both dasheen and eddoe genotypes. The final plant height of Sutra and Bentul (dasheen type) was $104.2 \%$ and $173.8 \%$, while of S28 and S19 (eddoe type) was $269.4 \%$ and $176.5 \%$ relative to dryland cultivation (DC). SWC also stimulated an increasing number of leaves, fresh and dry tuber weight, irrespective of genotypes. On the other hand, DC suppressed growth and yield in both dasheen and eddoe genotypes. The eddoe type is more prospective to the area with drought-prone incidents based on yield performance.

\section{ACKNOWLEDGEMENTS}

The research was partially supported by Benefit Sharing Fund (BSF) FAO Project in collaboration between Bogor Agricultural University (IPB), Indonesia and Malaysian Agriculture Research and Development Institute (MARDI) 2019-2021.

\section{REFERENCES}

Anjum SA, Xie X-Y, Wang L-C, Saleem MF, Man C, Lei W. 2011. Morphological, physiological and biochemical responses of plants to drought stress. African J Agric Res 6 (9): 2026-2032.

Arnold PA, Kruuk LEB, Nicotra AB. 2019. How to analyze plant phenotypic plasticity in response to a changing climate. New Phytologist 222 (3): 1235-1241. DOI: 10.1111/nph.15656

BB BIOGEN [Balai Besar Penelitian Bioteknologi dan Sumberdaya Genetik Pertanian]. 2020. Agriculture Gene Bank: Tanaman Talas. http://sdg.litbang.pertanian.go.id/?page_id=419 [Access in July 23, 2020]

Bonamour S, Chevin L-M, Charmantier A, Teplitsky C. 2019. Phenotypic plasticity in response to climate change: The importance of cue variation. Phil Trans R Soc B 374: 20180178. DOI: 10.1098/rstb.2018.0178

Chaïr H, Traore RE, Duval MF, Rivallan R, Mukherjee A, Aboagye LM, Van Rensburg WJ, Andrianavalona V, De Pinheiro Carvalho MAA, Saborio F, et al. 2016. Genetic diversification and dispersal of taro (Colocasia esculenta (L.) Schott). PLoS One 11 (6): e0157712. DOI: 10.1371/journal.pone.0157712.

Dulbari, Santosa E, Sulistyono E, Koesmaryono Y. 2017. Adaptation of wetland rice to extreme weather. J Trop Crops Sci 4 (2): 70-77.

Fiedler S, Vepraskas MJ, Richardson JL. 2007. Soil redox potential: Importance, field measurements, and observations. Adv Agron 94: 154. DOI: 10.1016/S0065-2113(06)94001-2

Ganança JFT, Freitas JGR, Nóbrega HGM, Rodrigues V, Antunes G, Gouveia CSS, Rodrigues M, Chaïr H, De Carvalho MÂA, Lebot V. 2018. Screening for drought tolerance in thirty three taro cultivars. Not Bot Horti Agrobot Cluj-Napoca 46 (1): 65-74.

Gosavi GU, Jadhav AS, Kale AA, Gadakh SR, Pawar BD, Chimote VP. 2014. Effect of heat stress on proline, chlorophyll content, heat shock proteins, and antioxidant enzyme activity in sorghum (Sorghum bicolor) at seedlings stage. Indian J Biotechnol 13 (3): 356-363. 
Gouveia CSS, Ganança JFT, Slaski J, Lebot V, Pinheiro de Carvalho MÂA. 2019. Stable isotope natural abundances $(\delta 13 \mathrm{C}$ and $\delta 15 \mathrm{~N})$ and carbon-water relations as drought stress mechanism response of taro (Colocasia esculenta (L.) Schott). J Plant Physiol 232: 100-106. DOI: 10.1016/j.jplph.2018.11.024.

Hetharie H, Raharjo SHT, Wattimena AY, Tomasoa R, Dahamarudin L. 2018. Genetic diversity and potentials of local sweet potato under partial submergence condition. J Budidaya Pertanian 14 (1): 1-7. DOI: 10.30598/jbdp.2018.14.1.1 [Indonesian]

Hussain M, Malik MA, Farooq M, Ashraf MY, Cheema MA. 2008 Improving drought tolerance by exogenous application of glycinebetaine and salicylic acid in sunflower. J Agron Crop Sci 194 (3): 193-199.

IPGRI [International Plant Genetic Research Institute]. 1999. Descriptors for Taro (Colocasia esculenta). IPGRI, Rome, Italy.

Irwan AW, Wicaksono FY. 2017. Comparations of soybean's leaf area measurement using gravimetry, regression, and scanning. J Kultivasi 16 (3): 425-429. [Indonesian]

Ivancic A, Lebot V. 2000. The Genetics and Breeding of Taro. CIRAD, France.

Mabhaudhi T, Modi AT, Beletse YG. 2013. Response of taro (Colocasia esculenta $\mathrm{L}$. Schott) landraces to varying water regimes under a rain shelter. Agric Water Manag 121: 102-112.

Mabhaudhi T, Modi AT. 2015. Drought tolerance of selected South African taro (Colocasia esculenta L. Schott) landraces. Exp Agric 5 1(3): 451-466.

Maretta D, Sobir, Helianti I, Purwono, Santosa E. 2020. Genetic diversity in eddoe taro (Colocasia esculenta var. antiquorum) from Indonesia based on morphological and nutritional characteristics. Biodiversitas 21(8): 3525-3533. DOI: 10.13057/biodiv/d210814.

Marschner P. 2012. Mineral Nutrition of Higher Plants. Adelaide (AU): Academic Pr.

Morales-Olmedo M, Ortiz M, Sellés G. 2015. Effects of transient soil waterlogging and its importance for rootstock selection. Chilean J Agric Res 75: 45-56. DOI: 10.4067/S0718-58392015000300006

Nurbaya SR, Estiasih T. 2013. Utilization of yellow corm taro (Colocasia esculenta (L.) Schott) in producing cookies. J Pangan Agroindustri 1 (1): 46-55. [Indonesian]

Nurilmala F, Hutagaol RP, Widhyastini IM, Widyastuti U, Suharsono. 2017. Somaclonal variation induction of Bogor taro (Colocasia esculenta) by gamma irradiation. Biodiversitas 18 (1): 28-33. DOI: $10.13057 /$ biodiv/d180105

Ravi V, Suja G, George J, Nedunchezhiyan M, Saravanan R, Byju G. 2015. Critical period of crop sensitivity to water deficit stress in elephant foot yam (Amorphophallus paeoniifolius). Indian J Agric Sci 85 (2): 274-277.

Ren BZ, Zhang JW, Dong ST, Liu P, Zhao B. 2016. Effects of duration of waterlogging at different growth stages on grain growth of summer maize (Zea mays L.) under field conditions. J Agron Crop Sci 6: 564 575. DOI: $10.1111 /$ jac. 12183

Rubaiyath Bin Rahman ANM, Zhang J. 2016. Flood and drought tolerance in rice: Opposite but may coexist. Food Energ Secur 5 (2): 76-88. DOI: $10.1002 /$ fes 3.79
Sagala D, Ghulamahdi M, Melati M. 2011. Nutrient uptake and growth of soybean varieties under saturated soil culture on tidal swamps. J Agroqua 9 (1): 1-10. DOI: 10.32663/ja.v9i1.40 [Indonesian]

Sahoo MR, Das Gupta M, Mukherjee A. 2008. Effect of in vitro and in vivo induction of polyethylene glycol mediated osmotic stress on hybrid taro (Colocasia esculenta (L.) Schott). Ann Trop Res 28(2): 1 11

Santosa E, Mine Y, Lontoh AP, Sugiyama N, Sari M, Kurniawati A. 2019. Gibberellic acid application causes erratic flowering on young corms of Amorphophallus muelleri Blume (Araceae). Hort J 88(1): 92-99. DOI: 10.2503/hortj.UTD-016

Santosa E, Sakti GP, Fattah MZ, Zaman S, Wachjar A. 2018b. Cocoa production stability in relation to changing rainfall and temperature in East Java, Indonesia. J Trop Crops Sci 5 (1): 6-17.

Santosa E, Sugiyama N, Hikosaka S, Kawabata S. 2003. Cultivation of Amorphophallus muelleri Blume in timber forests of East Java, Indonesia. Jpn J Trop Agr 47(3): 190-197.

Santosa E, Sugiyama N, Kurniawati A, Lontoh AP, Sari M, Krisantini. 2018a. Variation in floral morphology of agamosporous Amorphophallus muelleri Blume of natural and gibberellin flowerings. J Appl Hort 20 (1): 15-29. DOI: 10.37855/jah.2018.v20i01.03

Santosa E, Sugiyama N, Sulistyono E, Sopandie D. 2004. Effects of watering frequency on the growth of elephant foot yams. Jpn J Trop Agr 48(4): 235-239.

Setyowati M, Minantyorini. 2016. Corm weight stability character of genetic resources of taro (Colocasia esculenta L.) collected by ICABIOGRAD. Bul Plasma Nutfah 22 (2): 119-126.

Sims DA, Gamon JA. 2002. Relationships between leaf pigment content and spectral reflectance across a wide range of species, leaf structures and developmental stages. Remote Sensing Environ 81 (2-3): 337 354.

Singh SP, Setter TL. 2017. Effect of waterlogging on element concentrations, growth and yield of wheat varieties under farmer's sodic field conditions. Proc Natl Acad Sci India Sect. B 87 (2): 513520.

Striker GG. 2012. Flooding stress on plants: Anatomical, morphological and physiological responses, Botany, John Kiogora Mworia, IntechOpen, London. DOI: 10.5772/32922.

Sugiyama N, Santosa E. 2008. Edible Amorphophallus in IndonesiaPotential Crops in Agroforestry. Gadjah Mada University Press, Yogyakarta

Tian L, Li J, Bi W, Zuo S, Li L, Li W, Sun L. 2019. Effects of waterlogging stress at different growth stages on the photosynthetic characteristics and grain yield of spring maize (Zea mays L.) under field conditions. Agric Water Manag 218: 250-258.

Virtanen S, Puustinen M, Yli-Halla M. 2017. Oxidation of iron sulfides in subsoils of cultivated boreal acid sulfate soil fields-based on soil redox potential and $\mathrm{pH}$ measurements. Geoderma 308: 252-259. DOI: 10.1016/j.geoderma.2017.05.020

Wairiu M, Lal M, Iese V. 2012. Climate change implications for crop production in Pacific islands region, Food Production - Approaches, Challenges and Tasks, Anna Aladjadjiyan, IntechOpen, London. DOI: $10.5772 / 33885$. 